\title{
Can a person prepare to become a Christian? A Kierkegaardian response
}

\author{
ANDREW B. TORRANCE \\ St Mary's College, The School of Divinity, University of St Andrews, St Andrews, Fife, \\ KY16 9JU, United Kingdom \\ abt3@st-andrews.ac.uk
}

\begin{abstract}
Is it possible to prepare oneself to become a Christian? For Kierkegaard, there is no straightforward answer to this question, especially since such a transition depends upon a divine activity that is outside the realm of human control. Despite the challenge that this question poses, Kierkegaard's writings do provide us with a way to respond, and this response will be the subject matter of this paper. Following an analysis of his position, this paper will conclude that, although Kierkegaard recognizes that there are precedent ways of existing that are more conducive to becoming a Christian, it is not helpful to describe them as preparatory.
\end{abstract}

When a person undergoes a transformative experience, she finds herself existing in a way that she could not possibly have anticipated in advance of undergoing that experience. With transformation comes a new orientation to the world and, indeed, a new self-understanding. This raises a difficult question. How can a person prepare for the kind of existence that will result from a transformative experience? To address this question, we first need to think about the particular nature of the transformative experience that faces a person. Different transformative experiences raise their own distinctive challenges when it comes to addressing this question. ${ }^{1}$ The particular transformative experience that I shall be focusing on is Christian conversion. More specifically, I am going to think about how Søren Kierkegaard would respond to the question of whether a person can prepare to become a Christian.

As I seek to show, Kierkegaard does not think that conversion takes place by way of a specific, clear-cut experience. ${ }^{2}$ For Kierkegaard, '[c] onversion goes slowly' (JP 1, 420 / SKS $27,207)$. It is comparable to the transformation that a husband and wife experience in a marriage. Like marriage, the Christian life requires a person to commit her life to another person, to Jesus Christ; it requires her to commit herself prayerfully, imaginatively, and passionately to following Jesus Christ. By so doing, a person commits her life to another, without knowing all that this will entail, and without knowing what kind of person she will 
become within the covenant of this relationship. It is in the context of a committed relationship with Jesus Christ that a person begins to discover what it is like to participate in a life of faith. And when this happens in truth (in a way that corresponds to the divine truth that Jesus Christ mediates to the world), it involves what Laurie Paul refers to as 'an extended transformative experience'. (Paul (2014), 97). ${ }^{3}$ Over an extended period of time, a person will be delivered into a new life that she could not possibly have anticipated in advance of becoming a Christian.

What is more, for Kierkegaard, the essential condition of this transformative experience is encountering the active presence of God in her life. To become a Christian, a person needs to be reborn from above, according to the witness of the Spirit (John 3:3-8). 'Christian rebirth' involves 'a relationship not between man and man but between God and man'; it involves a relationship, which he refers to as 'a new creation' (JP 1, 649:19 / SKS 27, 396). The idea that Christian transformation requires God to be graciously at work in a person's life raises a whole new set of challenges when it comes to addressing the question, "can a person prepare to become a Christian?". This essay will explore some of the ways in which Kierkegaard negotiates these challenges.

By addressing this issue, this essay will also respond to Ingolf Dalferth's recent criticism of Kierkegaard, in which he claims that, for Kierkegaard, we 'have to prepare ourselves for, or at least become prepared for the workings of grace or we shall miss it'. (Dalferth (2005), 279). ${ }^{4}$ While I recognize that there is a deep ambiguity in Kierkegaard's argument that can invite such a claim, I also think that such ambiguity is to be expected when reflecting on the mysterious ways in which God relates to human beings in time. That said, I do not think that this ambiguity invites Dalferth's conclusion. As I reflect on whether Kierkegaard believes that a person can prepare to become a Christian, I shall defend Kierkegaard against Dalferth's reading of him. Additionally, I shall also challenge the misperception that Kierkegaard views Christian conversion as an existential process of selftransformation, ${ }^{5}$ rather than a process of transformation that takes place in a reciprocal relationship with God.

\section{On being ready for the unexpected}

Before turning to Kierkegaard, I want to turn briefly to consider Donald MacKinnon's reflections on the French Post-impressionist painter, Paul Cézanne. The reason for doing so is that MacKinnon's discussion of Cézanne offers a distinctive example of someone undergoing a transformation in a way that reflects certain aspects of Kierkegaard's account of Christian 
conversion. In particular, it gives us some insight into what it might mean for a person to prepare for the unexpected.

In his reflection of Cézanne, MacKinnon points out that it would have been impossible for Cézanne to experience and perceive the world in the way that he did had he not 'been the painter that in fact he was' (Mackinnon (1974), 107). It was in and through devoting himself to achieving the post-impressionist vision of art, which he was to embody, that Cézanne's 'perceptual experience achieved [a] complexity and subtlety' that distinguished him from the 'less disciplined and less creative spirits' (Ibid., 107).

Now, amongst these 'less disciplined and less creative spirits', we would have to include the younger Cézanne: that is, we would have to include Cézanne prior to his becoming the insightful post-impressionist painter that he later became. Cézanne was not born with a complex and subtle perceptiveness. Rather, he cultivated it through an extended period of discernment, which took his perception beyond its more pedestrian form. By drawing on the example of Cézanne, MacKinnon concludes that we must not become too comfortable with our standard perception of reality. We must learn 'to be ready for the unexpected', and this means developing an attitude that is 'uncongenial' to those who are set in their ways. ${ }^{6}$ We must become open to discerning more than that which is immediately apparent. By so doing, we allow ourselves to become transformed in and through our engagement with the surrounding world.

Cézanne's readiness for the unexpected required a perceptiveness that kept him from becoming bound to immediacy, from getting caught up in the regularities of earthly life, from synchronising with the pulse of the crowd. And it involved an enchantedness with which he came to interpret reality as having a brilliance that is not immediately apparent, on the surface. This discernment is what stopped Cézanne from settling into the uniformity of the natural world.

What makes Cézanne's discernment comparable to Christian discernment is that they are both characterized by a readiness for the unexpected, and an awareness of the transcendent, which resists the pull to become a cog in the machinations of the world-to become a mere feature of nature. The difference, however, is that, for Kierkegaard, Christian discernment is contingent upon the transcendent and unexpected one (God) establishing kinship with a person in time. By so doing, God enables a relationship with the transcendent that would have been beyond the reach of Cézanne's own imagination. What is more, while the Christian might not be content with settling into the ways of the world, she can find contentment by settling into a relationship with God. The restless imagination of Cézanne (qua painter) can never find such 
contentment. This is because the sense of transcendence that shaped Cézanne's artistry never relates him to the transcendent in the way that faith relates the Christian to the God who makes himself known. In Cézanne's search, the transcendent is always beyond the horizon of what he comes to know. Consequently, he can never find the sense of fulfilment (in his life as an artist) that the Christian enjoys in covenant relationship with God. ${ }^{7}$

For the purposes of this essay, I want to introduce an important qualification here. Being ready for the unexpected does not mean being mentally prepared for the unexpected. It cannot mean this. If one were able to prepare oneself mentally for the unexpected, there would need to be a sense in which the unexpected was not the unexpected. One can only mentally prepare for something if one has some awareness of that something prior to experiencing itthat is, if one has some idea of what to expect.

So, for example, on the one hand, there would seem to be plenty of things that a person can do to prepare to become a mother (there is even a well-known book entitled What to Expect When You're Expecting). On the other hand, a person cannot prepare for those things that are to be unexpected, such as those existential qualities that result from the transformative experiences of actually becoming a mother (assuming that becoming a mother is, in some way, a transformative experience - and most mothers will tell you that it is).

To be ready for the unexpected is to be continually open, not only to discovering new features of reality, but also to having the very nature of one's perception transformed; it is to be ready and open to being taken beyond one's immediate perception. Again, as we shall now see, there is an extent to which Kierkegaard recognizes that a similar attitude is conducive to becoming a Christian in a way that a closed-mindedness is not. That said, as I contend, it is unhelpful to view such an attitude as preparatory for becoming a Christian.

\section{Does Kierkegaard think that a person can prepare to become a Christian?}

For Kierkegaard, there is a sense in which becoming a Christian requires a readiness for the unexpected. He believes that there are certain things that a person can do that may ready a person to become a Christian: for example, praying, reading the bible, listening to the witness of a believing Christian. ${ }^{8} \mathrm{He}$ also recognizes that the particular dynamics of subjective human existence can have a pivotal role to play in readying a person to become a Christian. For example, he suggests that a person's passionate disposition — 'the thoughts of the heart' - have a decisive role in determining whether or not a person will come to faith (PC, 96 / SKS 12, 
105). ${ }^{9}$ And there are some features of this disposition that resemble Cézanne's readiness for the unexpected.

Yet, on the other hand, he also understands that neither a person's practices nor her particular subjective existence can, in and of themselves, prepare a person for being transformed into a life of faith and the perception this will generate. Any readiness that a person might achieve cannot know what to expect upon becoming a Christian. So, while there may be certain things that a person can do to increase the likelihood of becoming a Christian, these things will not prepare her for the entirely new quality of life that she will experience upon being transformed by the presence of God in time.

Some helpful illustrations of this point are provided by Laurie Paul. She notes, in one of her examples, that undergoing surgery to receive cochlear implants, and being in possession of the necessary medical conditions to receive the surgery, may provide the circumstances that will enable a person to be able to hear for the first time. However, they will certainly not, in and of themselves, prepare a person for the first-personal experience of hearing for the first time.

But there is also a critical difference here. It is likely that the person who is going to receive cochlear implants will be able to know, in advance, that she is ready to go through the process that will enable her to hear for the first time. However, for Kierkegaard, a person cannot know, in advance, that she is ready to become a Christian. A person can only know retrospectively that she was ready to become a Christian because she has become a Christian. Upon becoming a Christian, a person rejoices in the fact that she has been transformed by encountering the grace of God in her life; she rejoices in the fact that her life, in all its irreducible subjectivity, has been drawn into relationship with God.

This, however, is a simplification of Kierkegaard's position. So, now, I want to take some time to think more deeply about his understanding of Christian conversion. The limited focus of this essay will not allow for a close analysis of the detailed and careful way in which Kierkegaard responds to the question of how a person becomes a Christian. However, I shall offer an account of what I think are the essential elements in his discussion of conversion.

First, for Kierkegaard, a person cannot straightforwardly think herself into a qualitatively different sphere of existence, nor can she directly transition [Overgang] into it through sheer willpower because, in advance of her existing in it, there will be a sense in which it will be totally alien to her. ${ }^{10}$ To transition into such a sphere, for Kierkegaard, a person needs to set out on a pathos-filled venture into the unknown. ${ }^{11}$ And, to make a complete transition,

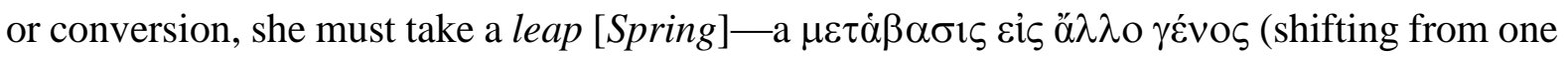


genus to another). This leap requires her to risk allowing herself to become transformed into a new way of existing. ${ }^{12}$

How, then, might a person involve herself in a process of conversion? To make this leap, a person will need to have some idea of where she is venturing. To become a Christian, a person needs to have some awareness of Christianity in advance of having any clarity as to what it actually means to be a Christian. However, while a prior awareness of Christianity is required, such awareness does not provide a person any direct access to the essential truth of Christianity. This is because, for Kierkegaard, a person can only truly relate to the truth of Christianity, to God, in and through a life of faith. A person cannot know what Christianity is, in truth, until she becomes a Christian. ${ }^{13}$ And, for this to happen, a person needs to be transformed by encountering the grace of God in her life. Therefore, studying Scripture and Christian doctrine will not directly bring a person into a personal relationship with the reality of God. ${ }^{14}$ It is the God who assumes human nature who is the all-transforming and irreducibly personal focus of the Christian faith. Therefore, a prior awareness of Christianity can only serve as the occasion for God to encounter that person and reconcile her into a life of faith. (See PF, 11 / SKS 4, 220).

\section{Johannes Climacus on becoming a Christian}

At this point, it can become quite difficult to work out how Kierkegaard thinks that a person can relate herself to the truth of Christianity. Indeed, Kierkegaard does not offer a precise answer to this question. His deep respect for the uncertainty of God's activity holds him back from providing an overly systematic account of how a person relates herself to the truth of Christianity. However, his non-Christian pseudonym, Johannes Climacus, is willing to offer a more systematic engagement with this question.

Climacus is described as an 'outsider' to the Christian faith, but an outsider who is preoccupied by the question 'How can I, Johannes Climacus, become a Christian?'. ${ }^{15}$ As a nonChristian trying to think about this question, Climacus does not show the same kind of caution that we see in Kierkegaard. He comes across as being more speculative and methodical in his thinking than Kierkegaard. Yet, as we shall see, he is also clear that becoming a Christian depends upon the power and presence of God in time - and, according to Christianity, God is not someone who can be incorporated into any world-historical system of understanding.

Climacus supposes that, to become a Christian, ${ }^{16}$ a person must approach the idea of God, or the idea of Christianity, with an existential pathos. She must approach this idea passionately, as someone who believes that she has nothing to offer except her need of God. 
(See CUP, 556-557, 581-582 / SKS 7, 505-506, 529). Going through these motions will not itself bring a person any closer to God. However, such motions can provide the 'impetus' for God then, in response (or in 'second place' [secundo loco]), to deliver that person from her sinful life into a life of faith - from a life in untruth to a life in truth (CUP, 559-560 / SKS 7, 508-509; see also JFY, 191 / SKS 16, 237-238). Climacus writes: 'the god [Guden] rescues from delusion the person who in quiet inwardness and honest before God is concerned for himself; even though he is ever so simple, the god leads him in the suffering of inwardness to the truth' (CUP, 615 / SKS 7, 559). ${ }^{17}$ In this passage we can see that, even when Climacus is stressing the subjective side of Christianity, he remains adamant that it is God who draws a person into relationship with the truth. When God is present in a person's life, in a way that brings about transformation, Climacus notes that there occurs a 'break with immanence' (CUP, 571 / SKS 7, 519).

This break with immanence, as M. Jamie Ferreira makes so clear, does not cause a person to lose continuity with herself, in every sense (Ferreira (2010), 6-24). In conversion, a person's humanity is not displaced; rather, it is transformed, heightened, and deepened (ibid. 19-21). Nevertheless, according to his understanding of Christianity, Climacus does not think that a person can transform herself into a life of faith. For Climacus, there is nothing inherent to a person's worldly existence that can enable her to deliver herself into the Christian faith. He understands that the Christian life is grounded in an encounter with 'God in time as an individual human being', who exists as 'something outside himself' (CUP, 561n., 556 / SKS 7, 510n., 506). ${ }^{18}$ The grace of God breaks into a person's life, as a spiritual activity that comes to her from beyond her own immanence - thereby causing a break in the natural course of her existence (CUP, 610 / SKS 7, 553). For Climacus, it is a particular historical relation to God in time that inspires a new Christian pathos ('a pathos of separation') with which God upbuilds a person in her faith (CUP, 582, 556-559 / SKS 7, 530, 505-508): a pathos that, given its absolutely different source of inspiration, must be recognized as qualitatively different from the universally accessible pathos that can be discovered by the inner workings of the human mind. ${ }^{19}$ The point of departure for becoming a Christian is thus a living relationship with God in history (CUP, 579, 583-584 / SKS 7, 526, 530-531). And this depends wholly upon a decisive 'moment' in which God encounters and reveals himself to a person in a way that transforms that person to relate to God in truth (PF, 13 / SKS 4, 222).

The 'moment' is key to understanding Climacus's understanding of Christianity. The limited scope of this paper will not allow for a comprehensive treatment of this issue (as it is considered, for example, in Philosophical Fragments). However, what I will say is that 
Climacus's emphasis on the role of the 'moment' is closely connected with Kierkegaard's critique of Hegelianism. The moment, for him, is a point in time in which the eternal God encounters an historical person from beyond time. With this paradoxical understanding, Climacus ensures that he does not collapse the eternal God into the world-historical process. For Climacus, God (and, therefore, a relationship that includes God) cannot be contained within the natural order. The God of Christianity remains free, unconstrained by the limits of the natural order. As such, every moment in which a person encounters God in time is made possible because God freely decides to encounter that person in time. While Kierkegaard's understanding of time warrants its own discussion and evaluation, it is helpful to note that Kierkegaard does not think that God exists within the contingent order. To put it in nonKierkegaardian terms, he believes that God is lord over creation history rather than subject to it. As such, each and every moment of God's engagement with history, and with everything in history, is always freely determined by the eternal God. ${ }^{20}$

In short, when God transforms a person within history, from beyond history, an event occurs that is beyond what is possible for a person on her own, in her own immanent history. By the grace of God, a person is given to participate in a new history of relationship with God. In this event, as Climacus puts it strongly, 'every remnant of original immanence is annihilated, and all connection cut away' (CUP, 572, 576 / SKS 7, 520, 523). God confronts a person miraculously in a way that causes that person, in this respect, to 'lose continuity with himself' and become 'a new creation' (CUP, 576 / SKS 7, 524).

In what sense, then, does a person both lose and maintain continuity with himself? In and through the process of conversion, for Climacus, a person continues to exist as the historical subject he has always been. However, when God reconciles him into a life of faith, his subjective history no longer remains closed to God. To put it in Climacus's terms, a person's original existence - in which he sinfully closes himself off to God- 'is annihilated' (CUP, 572, 576 / SKS 7, 520, 523). ${ }^{21}$ In faith, a person finds that God has opened him up to participate in a reciprocal relationship with God, and thus opened him up to the possibility of being transformed within this relationship. ${ }^{22}$ This means that any historical knowledge of Christianity, or any passionate interest in Christianity, which is prior to this transformation, can only ever be preliminary. If a person's existence is closed to God, it is not able to relate to God in truth. Therefore, a person's initial vision (her closed and unfaithful vision) of what Christianity can only ever be a projection of his 'pagan' understanding (CUP, 201, 293-294, 606 / SKS 7, 184, 267, 551). 


\section{Kierkegaard on becoming a Christian}

While Climacus and Kierkegaard relate to Christianity in very different ways ${ }^{23}$ it is fair to say that they share a very similar understanding of what Christianity is. For Kierkegaard, the Christian does not merely relate to God by learning about revelation from her Bible and then struggling to correspond to it. Becoming a Christian clearly presupposes that this will happen. However, Christian transformation relies on an outward relationship with God: with God who 'cannot be an object for [human] beings, because God is subject' (KJN 73 / SKS 20, 74; see also JP 2, 1449 / SKS 26, 281). It involves the transformation of a person by way of a spiritual activity that comes to her from beyond her own existence, from beyond a preacher's Sunday sermon, and, indeed, from beyond the pages of her Bible. ${ }^{24}$ Kierkegaard insists that we 'always need grace beforehand' (JP 2, 1493 / SKS 25, 223).

Kierkegaard also thinks that Jesus Christ is not merely a historical figure who leaves behind information that can serve to fill in the blanks in a person's immanent relation to God. Rather, Christ is the God-human 'mediator' in and through whom all persons can be drawn into a relationship with God, by the power of the Spirit. ${ }^{25}$ Consequently, it is not merely Christological or evangelical information that makes Christianity qualitatively unique, but the way in which the power of God in time actively enables a person to relate to God. So, it is not the case that once the Christian has accepted the Gospel message, she can then mediate the truth of Christianity to herself, in isolation from the presence of God. The only way whereby the Christian relates to the eternal truth, and continues to do so, is through a living relationship with God. On this account, it is not a person's passionate commitment to Christian teaching that is central, but rather, God's sustaining that person in her faith, thereby enabling her to relate both to God personally and thus to the truth that God is in himself. ${ }^{26}$

Grace, for Kierkegaard, does not simply perfect a person's natural existence; it transforms it. Prior to becoming a Christian, a person cannot know what to expect. There is no prospective continuity, and there is no possibility of a person predetermining the condition of God's engagement with him. A person cannot methodically summon the grace of God into his life, and thereby use God to deliver himself into a life of faith. ${ }^{27}$ Unlike immanent forms of religiousness, it is not the case in Christianity that ' $[\mathrm{w}]$ hen a person rubs it [the wonderful lamp of freedom] with ethical passion, God comes into existence for him' (CUP, 138 / SKS 7, 129). ${ }^{28}$ Becoming a Christian involves a free subject to free subject relationship that may require a person to be patient in his passion to know God (see KJN 5, 124-125 / SKS 21, 119). Any existential continuity, therefore, can only be discerned retrospectively and in such a way that 
God's mediatory, transformative and redemptive activity is understood to be both foundational and also unanticipatable. When a person is transformed by grace, he no longer relates naturally to God as if God were a conceptual postulate, an existential goal, or an object of his imagination.

Does this mean that the Christian is required to forget what it means to exist as a human being? No, by being drawn into relationship with God (the eternal truth), the Christian is given to know in truth what it means to be human, and to be so before the God who creates and sustains her. For Kierkegaard, a person discovers her humanity when her existence corresponds to the power that created her. ${ }^{29}$ She discovers her humanity by coming to know the God before whom she stands. And she comes to know this, in truth, by the grace of God (see PF, 46 / SKS $4,252)$.

So, what can be said about whether a person can ready herself to become a Christian? To come to faith in God, Climacus suggests, a person must loosen her grip on her desire to see God demonstrated to her directly; she needs to let go of the priority she gives to her own immediate understanding and imagination. As he puts it, she needs to 'let go of the demonstration' in a 'leap' that he describes as meine Zuthat (my contribution) (PF, 42-43 / SKS 4 , 248). By 'letting go', a person resists the temptation to try to work God out in her own terms before turning to God for relationship. She becomes ready for the unexpected and submits herself to God, humbly placing her trust in God for everything.

For Kierkegaard, the venturing or willingness that characterizes the leap does not in itself prepare a person to know God. As Murray Rae notes, the leap that a person contributes 'is more aptly defined as the removal of an obstacle to conversion. That obstacle is human pretence - the pretence that reason or the understanding enables us to attain the Truth on our own.' (Rae (1997), 166). ${ }^{30}$ To be clear, by seeking to set aside one's own pretence, a person does not positively prepare herself to become a Christian. It simply makes her more open for the unexpected: it makes her more open to the possibility of encountering something for which she cannot prepare herself; and it makes her more open to the possibility that her immediate perception of reality might be confused. For Kierkegaard, it would seem that such openness makes a person's existence more conducive to becoming a Christian.

This seems right. If, for example, an atheist, such as Richard Dawkins, were less confident in his own capacity to understand the nature of reality, and more open to the possibility of God's existence, it would seem fair to say that he would be more likely to become a Christian. Or, to put it another way, such humility would seem to increase the likelihood of him participating in the kind of occasion that is conducive to becoming a Christian: such as an 
occasion of prayer, attending a Church service, or listening to the witness of a believing Christian.

But, again, prospectively, a person cannot know that she is open to the grace of God. She can only know retrospectively that she was open to God, because she has become a Christian. A person knows that she is blessed because she has been given the eyes to see and the ears to hear (Matt. 13:16). And, when this happens, the Christian does not boast of her own ability to open herself to God, but boasts of the grace of God, which drew (and is drawing) her into a life of faith. The Christian does not boast of the capacity of her own "flesh and blood" to perceive the truth of Gospel message, but of the revelation of the "Father who is in heaven" (Mt. 16:17).

When a person turns to the God who she does not yet know, she awaits a transformative experience that is very different from the transformative experience that might take place in a marriage between equals, or that a parent might experience when raising a child - to refer to Laurie Paul's examples. ${ }^{31}$ If anything, she awaits an experience that is comparable to the transformative experience that an infant might come to experience when kept in a loving relationship by a parent. In this relationship, the infant comes to know the parent she did not immediately have the ability to know. The reason for this is that the relationship with Godwhich undergirds Christian conversion - is not chosen or maintained in the way that a person might be able to choose or maintain a relationship with a spouse or a child. While there are choices that need to be made to become a Christian, for Kierkegaard, the Christian does not have the freedom to realize the relationship with God for herself. A person cannot simply commit herself to a known set of circumstances by which she can know that she will undergo the transformative experience that takes place in a relationship with God. Instead, she must trust that God will draw her to himself and keep her in this relationship, transforming her in ways that she cannot even begin to understand.

Kierkegaard does not know the mind of God. Again, for this reason, he does not attempt to offer a systematic explanation as to why there are certain dynamics within the contingent order that can increase the likelihood of a person becoming a Christian. Nonetheless, he does assume that this is case. For him, if we do not acknowledge that human agency has a pivotal role in the process of 'becoming a believer', we end up with 'a fatalistic understanding of election by grace' (KJN 6, 420-421 / SKS 22, 415). Rather than human beings being the variable in deciding whether or not a person becomes a Christian, God becomes the variable. And this is not an option for Kierkegaard. As such, it is somewhat understandable why Dalferth would criticize Kierkegaard for suggesting that a person can prepare for the workings of grace. Yet 
Dalferth's criticism is also somewhat uncharitable. Prospectively, Kierkegaard does not think that a person can know what it means to prepare to become a Christian-let alone actually prepare herself to make this happen. No human mind has an inside knowledge that can know precisely how, when, why, or whether God will draw a person into the Christian life. Kierkegaard's theological vision simply does not have the self-confidence to assume that human beings possess an intentional command over the workings of grace.

There is something else that is worth mentioning here, which may further clarify Kierkegaard's own position. As Murray Rae points out, 'the leap' is a Climacean category; this category, he notes, 'is almost completely absent from the writings of the so-called Christian authors, Anti-Climacus and Kierkegaard himself' (Rae (1997), 22). That is, 'the leap' is the generic category of a non-Christian who is pondering how to become a Christian. Kierkegaard does not make the same use of the leap. When Kierkegaard looks back over his life as a Christian, he does not recount the leaps that he made to become a Christian. Rather, he speaks of God's governance (Styrelse) that supported him 'indescribably much' (KJN 5, 243 / SKS 21, 233). He speaks of the Holy Spirit who gives faith (FSE, 81 / SKS, 13, 103). And he speaks of the love of God made known to the world in Jesus Christ:

Lord Jesus Christ, you who loved us first, you who until the last, loved those whom you had loved from the beginning, you who until the end of time continue to love everyone who wants to belong to you-your faithfulness cannot deny itself. Alas, only when a person denies you can he force you, so to speak, you the loving one, also to deny him. (CD, 282 / SKS 10, 103).

\section{Conclusion}

When becoming a Christian, for Kierkegaard, a person trusts and hopes that God is at work in her life; she must 'believe in a providentia specialissima [special providence]' (JP 2, 2083 / SKS 26, 241). However, she cannot know this with certainty, nor can she have any command over God's activity. Indeed, for Kierkegaard, there is a sense in which a person cannot even know for certain whether she has actually become a Christian - insofar as she cannot directly see God delivering her into a life of faith. So, becoming a Christian is not as clear-cut as hearing for the first time with the help of cochlear implants. To an extent, it is more comparable to getting married or achieving a post-impressionist vision of art. However, it is even less clearcut than these experiences because it depends upon a spiritual activity that comes to a person 
mysteriously, from beyond her subjective experience of the world and, indeed, from beyond the surface phenomena of this world. This activity can only be known by the eyes of faith [Troens $\varnothing i e]$, and even these eyes are having to look through a glass darkly (1 Cor. 13:12; see JP 4, 3916 / SKS 27, 303).

So, when considering whether he himself is a Christian, Kierkegaard notes: '[I] aspire to it, fight for it, pray about it, and trust to God I am a Christian' (PV, 129 / SKS 16, 111). However, out of his deep respect for Christianity, he is trepidatious about asserting his status as a Christian. ${ }^{32} \mathrm{He}$ explains: 'to say about oneself that one is a Christian means to speak with God, and that therefore a human being must speak with fear and trembling' (PV, 140 / SKS 16, 122). The problem with certainty is that it intimates that a subject has a command over her relationship with the object of her knowing; it suggests a form of command that is not proper to a faithful relationship with God. Genuine faith in God is characterized by a humble recognition of the incompleteness and provisionality of one's beliefs: a recognition that keeps a person turning to God for upbuilding in the struggle to become a Christian.

We can see, therefore, why Kierkegaard would resist the suggestion that a person can prepare to become a Christian. His appreciation for the uncertainty of faith does not concur with the suggestion that grace can be anticipated in the mind of a person who is thinking about becoming a Christian. Again, while he is happy to acknowledge that there are human practices and mindsets that seem pivotal for becoming a Christian, he does not present them in any straightforward way as conscious preparation for the miracle and mystery of grace. Not for a moment does he think that a person is privy to (let alone able to prepare herself for) the way that God works in the world. What Kierkegaard does affirm, albeit unsystematically, is that a humble and passionate interest in a personal relationship with the living God is conducive to becoming a Christian in a way that a speculative or inward-looking analysis of Christianity is not.

What is central for Kierkegaard is not a theory of conversion but the reality to which conversion corresponds. This reality, the reality of grace, is not something to be passively observed, systematized, naturalized, or domesticated. Grace is not to be introduced 'as a matter of course'-a mere step in the process of coming to faith-'which, after all, means that it [grace] is taken in vain' (PV, 16 / SKS 13, 24). It is present as an activity that comes from beyond human existence to draw persons to embrace God wholeheartedly with a humble and loving adoration. And whether grace draws a person into a personal relationship with the God, 'depends on whether it so pleases God' (JP 2, 1452 / SKS 26, 345). That being said, a person can trust that God lovingly wills to draws all persons to himself, and so the person who seeks 
God can hope and trust that she will come to find the grace of God working in her life (Mt. 7:7; Lk. 11:9).

To conclude, for Kierkegaard, the Christian's story of her conversion is not to be told as a story of her own existential adventure, or of her own transformative experience. Rather, it is to be told as the story of God drawing that person to himself, in and through the person of Jesus Christ, and, indeed, through the power of the Holy Spirit. The story of Christian conversion is to be told as the story of God finding that person in the wilderness. It is not a story of how a person prepared herself to find God in the wilderness.

Of course, the story of a person's conversion can be narrated in either way. But, for Kierkegaard, one way is faithful and the other is not. In retrospect, for the Christian, the story of conversion is a story of God's governance, the story of God's faithfulness; it is not the story of an imaginative person, but the story of the mediator, the high priest, who graciously delivers a person across a chasm that would otherwise be uncrossable or, we might say, unleapable.

So the Christian must resist the temptation to start the story of her conversion with "I": "I grew up in a Christian home", "I went to a Christian camp", "I found God at a particularly difficult time in my life". If a Christian begins in that way, she must quickly pause and correct herself with the Apostle Paul's words "yet not I" [ouk egō de], and confess that her conversion is enabled by "the grace of God that is with me" (1 Cor. 15:10). ${ }^{33}$

But why would the Christian confess that her faith is grounded in the grace of a God who is hidden from view? Would this not convey to the (secular) world that she is a blind fideist - someone committed to the activity of an invisible being? For Kierkegaard, the Christian does this because it is a part of her faithful calling to recognize and confess that God has spoken to her - that God has called her out of her confusion into a life that is devoted to the living God. Any temptation to reduce this calling to the ramblings of her own imagination would be to prompt a forgetfulness of her calling. It would be to deny the reality of God, and turn her own idea of God into the object of her faith. Furthermore, it would be to disregard the one true grounding of the Christian faith - the God who delivers a person into a life of truth. So, for Kierkegaard, the Christian must always testify that God prepares her to become a Christian in a way that she could never do for herself.

\section{References}

BAGGAR, MATTHEW (2007) The Uses of Paradox: Religion, Self-Transformation, and the Absurd (New York: Columbia University Press). 
BARRETT, LEE (1994) 'The paradox of faith in Philosophical Fragments: gift or task?', in Robert Perkins (ed.) International Kierkegaard Commentary: 'Philosophical Fragments' and 'Johannes Climacus', (Macon GA: Mercer University Press), 261-284. DALFERTH, INGOLF (2005) 'Becoming a Christian according to the Postscript: Kierkegaard's Christian hermeneutics of existence', in N.J. Cappelørn and H. Deuser (eds) Kierkegaard Studies Yearbook 2005, (Berlin and New York: Walter de Gruyter), p. $242-281$.

EVANS, C. STEPHEN (2006), 'Can God be hidden and evident at the same time? Some Kierkegaardian reflections', in Faith and Philosophy 23, 241-253.

FERREIRA, M. JAMIE (2010) 'The "Socratic secret": The postscript to the Philosophical Crumbs', in Rick Furtak (ed.) Concluding Unscientific Postscript: A Critical Guide, (Cambridge: Cambridge University Press), 6-24.

KIERKEGAARD, SØREN (1968-1970) Søren Kierkegaard Papirer, vols. I-XI-3, Peter Andreas Heiberg, Victor Kuhr and Einer Torsting (eds) (Copenhagen: Gylendalske Boghandel, Nordisk Forlag, 1909-48); $2^{\text {nd }}$ ed. I-XI3 and supplementary vols. XII-XIII, Niels Thulstrup (ed.) (Copenhagen: Gylendal) (abbreviated to Pap).

(1967-78) Journals and Papers vols. 1-6, Howard V. and Edna H. Hong Howard and Edna Hong (eds and trs) (Bloomington IN: Indiana University Press) (abbreviated to $\mathrm{JP})$.

(1980) The Concept of Anxiety, Reidar Thomte (ed. and tr.) (Princeton NJ: Princeton University Press) (abbreviated to CA),

(1980) The Sickness unto Death: A Christian Psychological Exposition for Upbuilding and Awakening, Howard and Edna Hong (eds and trs) (Princeton NJ: Princeton University Press) (abbreviated to SUD).

(1985) Philosophical Fragments, Howard and Edna Hong (eds and trs) (Princeton NJ: Princeton University Press) (abbreviated to PF).

(1990) For Self-Examination, Howard and Edna Hong (eds and trs) (Princeton NJ: Princeton University Press) (abbreviated to FSE).

(1990) Judge for Yourself!, Howard and Edna Hong (eds and trs) (Princeton NJ: Princeton University Press) (abbreviated to JFY).

(1992) Concluding Unscientific Postscript to Philosophical Fragments, Howard and Edna Hong (eds and trs) (Princeton NJ: Princeton University Press) (abbreviated to CUP). 
(1997) Christian Discourses, Howard and Edna Hong (eds and trs) (Princeton NJ: Princeton University Press) (abbreviated to CD).

(1997-2013) Søren Kierkegaard Skrifter vol. 27, Niels Jørgen Cappelørn, Joakim Garff, Kette Knudsen, Johnny Kondrup, Alastair McKinnon, and Finn Hauberg Mortensen (ed.) (Copenhagen: Gads Forlag) (abbreviated to SKS).

(1998) The Point of View for My Work as an Author, Howard and Edna Hong (eds and trs) (Princeton NJ: Princeton University Press) (abbreviated to PV).

(2007 ff.) Kierkegaard's Journals and Notebooks, Niels Jørgen Cappelørn, Alastair Hannay, David Kangas, Bruce H. Kirmmse, George Pattison, Vanessa Rumble, and K. Brian Söderquist (eds) (Princeton NJ: Princeton University Press) (abbreviated to KJN). MACKINNON, DONALD (1974) 'Empiricism and Transcendence', in The Problem of Metaphysics (Cambridge: Cambridge University Press), 104-113.

PAUL, LAURIE (2014) Transformative Experience (Oxford: Oxford University Press).

RAE, MURRAY (1997) Kierkegaard's Vision of the Incarnation (Oxford: Oxford University Press).

TORRANCE, ANDREW (2014) 'Do You Have the Heart to Come to Faith? A Look at AntiClimacus' Reading of Matthew 11.6', The Heythrop Journal 55, 860-870.

\section{Notes}

\footnotetext{
${ }^{1}$ For example, in her recent book, Transformative Experience, Laurie Paul offers an array of distinctive reflections on the various transformative experiences that she considers: such as becoming a vampire, becoming a mother, or getting cochlear implants that will enable her to hear for the first time. Each of these circumstances have their own unique dynamics, but they also each face the same difficulty, a difficulty that I am considering in this paper. How can a person make an informed choice about whether or not to undergo a transformative experience?

${ }^{2}$ As such, conversion is significantly dissimilar to the 'immediate, sharp transitions' that occur when being bitten by a vampire, having a child, or receiving cochlear implants - to the 'special cases where the transformative nature of the experience is easily identifiable'. (Paul (2014), 104). In contrast to these experiences, Paul also devotes time to considering transformative experiences that 'involve change that occurs over a period of time, or occurs in the distant future from the time at which you must make the decision to act'. She writes: 'In this way, ordinary approaches towards central, life-defining choices, like the choice to get married, the choice to adopt and parent a young child into adulthood, and the choice of a career, can involve transformative choices. Here, you must make a choice that affects your temporally extended self, a choice to initiate an experience that lasts for months or years, or your current time slice must make a choice that determines the lived experience of a time slice in your distant future'. (Ibid., 94).

${ }^{3}$ Paul considers the examples of being a parent and taking on a medical career as extended transformative experiences. (Paul (2014), 98-103).

${ }^{4}$ In this essay, Dalferth critiques Kierkegaard for 'putting the cart before the horse' (Dalferth (2005), 279). He interprets Kierkegaard as suggesting that '[i]t is not grace that defines how it is received, but our human receiving that defines how grace is received, when it can be received and what is received as grace'. (Ibid., 279). This critique is advanced in response to what Dalferth thinks is 'a deep ambiguity and unresolved tension' in the account of becoming a Christian that we find in Concluding Unscientific Postscript. On the one hand, he recognizes that the 'argument in Postscript depends from the first to the last page on the priority of God's creative grace over our ways of receiving it'. (Ibid., 279). However, on the other hand, he also thinks that Postscript
} 
'presents the spheres of existence as defining what we can see and grasp and understand as God's presence and grace'. (Ibid., 279).

${ }^{5}$ See, for example, Baggar (2007), 28.

${ }^{6}$ For MacKinnon, this is 'peculiarly uncongenial' both to the 'positivist and metaphysical dogmatist'. (Mackinnon (1974), 113)

${ }^{7}$ See Kierkegaard's discourse on Mt. 11:28, 'Come here to me, all who labor and are burdened, and I will give you rest, in CD, 262-267 / SKS, 267-275.

${ }^{8}$ Kierkegaard's pseudonym, Johannes Climacus indicates that, for a person to come to faith, she will need to encounter 'a believer's report' [den Troendes Efterretning]: a report that says something akin to "We have believed that in such and such a year the god appeared in the humble form of a servant, lived and taught among us, and then died"'. (PF, 104 / SKS 4, 300). What is significant about the witness of a believer is that it presents Jesus Christ as the object of faith (rather than, for example, an object of historical-critical study).

${ }^{9}$ See also PC, 140 / SKS 12, 144. I argue this point more fully in my article, 'Do You Have the Heart to Come to Faith? A Look at Anti-Climacus' Reading of Matthew 11.6'.

${ }^{10}$ Accordingly, Kierkegaard's pseudonym, Vigilius Haufniensis, notes that the nature of the 'qualitative leap' that takes place in the fall (in which man falls into a qualitatively different sphere of existence) would be beyond the scope of psychological investigation. (CA, 38-41, 47-52 / SKS 4, 344-345, 352-356).

${ }^{11}$ This is how a person who is thinking about becoming a Christian should think about what is required to become a Christian. Clearly, not everyone will become a Christian in this way. For example, in Acts, we find a number of accounts of conversion that are much more immediate: accounts of converts who did not seem to go through a pathos-filled adventure into the unknown. For example: the first converts (Acts 2.37-42), the conversion of Saul (Acts 9.1-19), the conversion of Lydia (Acts 16.11-15), and the conversion of the Philippian jailer (Acts 16.2740).

${ }^{12}$ To a certain extent, this leap requires a person to ready herself for the unexpected. However, for Kierkegaard, a person should also show some restraint. Like MacKinnon, Kierkegaard does not think that a person should exist in such a way as to allow herself to be passively overcome by unexpected experiences - a person should not be ready to surrender herself to the unexpected 'as if it were all-embracing revelation'. (MacKinnon (1974), 113). It would be unwise for a person to exist in a way that would allow her to become easily carried away by an immediate fascination with an unexpected revelation - by something totally unfamiliar. For Kierkegaard, person must have a hold on her existence; she must be intentional in her decisions over which direction her life should take (see CUP, 311-312 / SKS 7, 283). Nevertheless, upon coming to know God, and upon becoming a Christian who views a relationship with God as the absolute telos of her existence, that person must become willing to surrender herself wholeheartedly to God. (See CD, 251 / SKS 10, 265).

${ }^{13}$ Kierkegaard writes: "Being a Christian is defined not by the "what" of Christianity but by the "how" of the Christian.' (CUP, 610 / SKS 7, 554). This meant not only emphasizing the grace of God in the Christian life but also stressing that the Christian must strive to live in a way that takes her relationship with God seriously. The Christian must interpret her relationship with God as her eternal happiness; she must commit her life to worshipping God, and she must do so with an understanding that she is nothing before God. To become a Christian, a person must think about what it means to become a Christian and struggle to act accordingly. When she does so, her reflection is not simply the grace of God operating within her. For Climacus, becoming a Christian involves grappling with the call of Christianity, and this seems to involve a reciprocal relationship between the grace of God and a person's immanent existence.

${ }^{14}$ As Climacus notes: 'Awareness is by no means partial to faith, as if faith proceeded as a simple consequence of awareness.' (PF, 93 / SKS 4, 291).

${ }^{15}$ In his analysis of Christianity, in Concluding Unscientific Postscript, Climacus offers quite an existential account of Christianity. He notes: 'the issue is not about the truth of Christianity but about individual's relation to Christianity'. (CUP, 15 / SKS 7, 24).

${ }^{16}$ To understand what Climacus is doing, it is important to be clear that the account of becoming a Christian that Climacus advances is primarily directed at himself, as someone asking the question, 'How can I become a Christian?'.

${ }^{17}$ This passage could be seen to find support in James 4:8.

${ }^{18}$ This is also made plain in Philosophical Fragments, in which he puts forward an account of conversion that, in Postscript, he associates with Christianity.

${ }^{19}$ When God draws a person into a life of faith, that person will be distinguished from those who do not have faith. The problem with this suggestion, as Climacus acknowledges, is that it could be taken to imply that the Christian is being given 'preferential treatment', and, he notes, 'if a Christian selfishly perceives it as this, we have the desperate arrogation of predestination'. The Christian would seem to be singled out from 'others who do not have or are unable to have preferential treatment'; and this includes 'the countless ones who are excluded through no fault of their own but by the accidental circumstance that Christianity has not yet been proclaimed to them'. Climacus does not devote much attention to this issue, but merely states it as a difficulty that arises in a 
Christian understanding of faith. Also, he does not think that this preferential treatment will immediately come across as preferential treatment in this world. By becoming a Christian, a person is drawn into a life that is 'distinguished by suffering' (CUP, 582-583 / SKS 7, 529-530).

${ }^{20}$ Lee Barrett helpfully explains, 'any preparation for grace could jeopardize the decisiveness of the moment. The individual would be grateful to God for the gift of grace, but grateful to oneself for becoming eligible to receive the gift. But if the moment is to have decisive significance, the recipient can take no credit for being in a position to receive grace. The logic of absolute gratitude, trust, and dependence requires the denigration of the previous life situation. Gratitude is maximised if salvation is not only a gift, but also a gift which was neither expected nor sought.' (Barrett (1994), 270).

${ }^{21}$ In a person's prior sinful existence, Climacus describes, the sinner 'holds himself captive' (PF, 17 / SKS 4, 226; see also CUP, 208 / SKS 7, 191; CA, 22 / SKS 4, 330; PC, 151 / SKS 12, 155).

${ }^{22}$ Climacus does not develop this point with reference to the work of the Holy Spirit. However, Kierkegaard himself asserts that '[t]he Spirit brings faith, the faith - that is, faith in the strictest sense of the word, this gift of the Holy Spirit'. (FSE, 81 / SKS 13, 103). He also maintains that the Spirit enables us to know God the Son, the Mediator, who directs us to God the Father: God 'becomes my Father in the Mediator by means of the Spirit'. (JP 2,1432 / SKS 25, 140-141).

${ }^{23}$ Indeed, Kierkegaard notes that 'it would be ludicrously confusing to attribute to me everything the poeticized personalities [such as Climacus] say’. (JP 6, 6786 / Pap X-6 B 145; see also CUP, 625-630 / SKS 7, 569-567).

${ }^{24}$ For Kierkegaard, 'The Holy Scriptures are the wayside sign [Veiviseren], Christ is the way' (KJN 2, 105 / SKS 20, 105).

${ }^{25}$ Drawing on Jn. 6.45, Kierkegaard notes, 'God directs us to the Son, to the Mediator' and pronounces 'In the Mediator I can be a father to you.' He also notes that the Spirit must help us to know the Son, the Mediator, who directs us to the Father: God 'becomes my Father in the Mediator by means of the Spirit'. (JP 2, 1432 / SKS 25 , 140-142). Kierkegaard also writes: 'A Mediator is necessary for me, among other reasons, simply to make me aware that it is God with whom, as we say, I have the honor of speaking; otherwise a man can easily live on in the indolent conceit that he is talking with God, whereas he is only talking with himself. (JP 2, 1424 / SKS 24, 237).

${ }^{26}$ Kierkegaard does not attempt to offer a systematic account of how we should understand the relationship between divine sovereignty and human autonomy. For him, both divine and human agency have a decisive role to play in the process of becoming a Christian. However, the question of how exactly the two relate to one another is not, for him, something that human beings have the capacity to resolve systematically, by way of their finite understanding.

${ }^{27}$ See Kierkegaard's allusion to Jn. 3:8 in CD, 253 / SKS 10, 267. Although, in certain respects, Kierkegaard engages in systematic argument, he does so with a concern to critique overly systematic accounts of Christianity. For Kierkegaard, a methodical account of exactly how or why a person becomes a Christian is beyond the scope of systematic investigation. 'Faith is always related to what is not seen; in the setting of nature (in opposition to the senses) to what is invisible [Usynlige]; in the setting of spirit (spiritually) to what is improbable [Usandsynlige].' (KJN 4, 74 / SKS 20, 75).

Also, in his writings, Kierkegaard does not attempt to offer a precise explanation of how divine and human action relate to one another in the process of becoming a Christian. 'A providence [Forsyn] is no easier to understand (to grasp) than redemption [Forlфsningen] — both can only be believed.' (JP 3, 3628 / SKS 27, 349 emphasis original).

28 Commenting on passages such as this, C. Stephen Evans notes that Climacus is here speaking phenomenologically. When a human being is not spiritually attuned, God is not experienced as real, and in a sense God is not real for that person.' (Evans (2006), 244). I think this is right. However, I would want to qualify that, if this is to be understood Christianly, we need to be clear that God is actively involved in the spiritual attuning.

${ }^{29}$ As Kierkegaard's Christian pseudonym Anti-Climacus presents it, a person discovers what it means to be a self when her existence that corresponds to 'the power that established it'. (SUD, 20-21 / SKS 11, 136-137).

${ }^{30}$ Also, as Kierkegaard himself writes: 'Man's highest achievement is to let God be able to help him.' (JP 1, 54 / SKS 27, 569-570; see also JP 2, 1492 / SKS 25, 177).

${ }^{31}$ For Laurie Paul, there is something special about religious experience, which means that it 'deserves more extensive discussion'. (Paul (2014), 104). While she does not offer a more extensive discussion of religious experience in her book on Transformative Experience, she does mention that she is working on an article on 'Transformative Religious Belief' that is (still) yet to come out. (Ibid., 104 n. 58).

${ }^{32}$ Although Kierkegaard does qualify: 'If my relation were to pagans... then in opposition to them I would have to say that I am a Christian. But I am living in Christendom, among Christians, or among people who say they are Christians.' (PV, 138-139 / SKS 16, 120).

${ }^{33}$ Kierkegaard writes: 'God has allowed human beings to be able to work in order to give them an enjoyment, a feeling of independence'. (JFY, 185 / SKS 16, 232). After making this point, he provides his well-known illustration of the mother who wants to give her child, little Ludvig, the delightful perception that he is pushing 
the stroller himself. This activity, however, is not one that is possible for Ludvig by himself. So, while the mother allows Ludvig to struggle to push the stroller for himself, it is actually her who is the one who has to do the pushing from behind. Such a situation, for Kierkegaard, is comparable to the person who struggles to live out the Christian life, while it is actually God who is enabling her to live out the Christian life. 